\title{
ARTICLE
}

\section{Nitrogen-embedded buckybowl and its assembly with $\mathrm{C}_{60}$}

Hiroki Yokoi ${ }^{1}$, Yuya Hiraoka', Satoru Hiroto ${ }^{1}$, Daisuke Sakamaki ${ }^{2}$, Shu Seki ${ }^{2}$ \& Hiroshi Shinokubo ${ }^{1}$

Curved $\pi$-conjugated molecules have attracted considerable interest because of the unique properties originating from their curved $\pi$ surface. However, the synthesis of such distorted molecules requires harsh conditions, which hamper easy access to heteroatom-containing curved $\pi$ systems. Here we report the synthesis of a $\pi$-extended azacorannulene with nitrogen in its centre. The oxidation of 9-aminophenanthrene provides tetrabenzocarbazole, which is converted to the azabuckybowl through palladium-catalysed intramolecular coupling. The electron-donating nature and curved $\pi$ surface of the azabuckybowl enable its tight association with $\mathrm{C}_{60}$ in solution and solid states. High charge mobility is observed for the azabuckybowl/ $\mathrm{C}_{60}$ assembly. This compound may be of interest in the fields of curved $\pi$ systems as fullerene hosts, anisotropic $\pi$ donors and precursors to nitrogen-containing nanocarbon materials.

\footnotetext{
${ }^{1}$ Department of Applied Chemistry, Graduate School of Engineering, Nagoya University, Nagoya 464-8603, Japan. ${ }^{2}$ Department of Molecular Engineering Graduate School of Engineering, Kyoto University, Kyoto 615-8510, Japan. Correspondence and requests for materials should be addressed to S.H. (email: hiroto@apchem.nagoya-u.ac.jp) or to H.S. (email: hshino@apchem.nagoya-u.ac.jp).
} 
C urved $\pi$-conjugated molecules have captivated numerous scientists $^{1-4}$. Curving a $\pi$ system induces a large displacement from a plane to construct threedimensional structures ${ }^{5-10}$. Besides their figurative beauty, the curved $\pi$ surface generates unique functions such as chiroptical properties, anisotropic electron transitions and dynamic motion in solution and solid states ${ }^{11-13}$. To enhance these characteristics, the introduction of heteroatoms is an effective strategy. However, the synthesis of heteroatom-containing curved $\pi$ systems remains a challenge ${ }^{14,15}$. The preparation of distorted $\pi$ systems requires harsh reaction conditions that do not tolerate heterocyclic molecules.

Buckybowls, that is, bowl-shaped molecules such as corannulenes ${ }^{16}$ and sumanenes ${ }^{17}$ represent important curved $\pi$-conjugated molecules, which can be precursors for the bottom-up synthesis of fullerenes and nanotubes. In 1966, Barth and Lawton ${ }^{16}$ reported the first chemical synthesis of corannulene. Since Scott and Siegel's groups ${ }^{18-21}$ developed their straightforward synthesis of corannulene, numerous bowl-shaped hydrocarbons have been synthesized. On the other hand, the nitrogen-embedded bowl-shaped molecules have been sought as model compounds for azafullerenes and nitrogen-doped carbon nanotubes $22-24$. Furthermore, dramatic changes in electronic structures of buckybowls by nitrogen are expected. However, the synthesis of buckybowls with internal nitrogen atoms has been still challenging ${ }^{25}$. Oxidative fusion approaches are not compatible with electron-rich nitrogen because of its less tolerant nature for oxidation.

Recently, our group reported the oxidative dimerization of aminoarenes to distorted $\pi$-conjugated molecules in a onestep operation ${ }^{26,27}$. We here disclose that the oxidation of 9-aminophenanthrenes affords tetrabenzocarbazoles in good yields. Furthermore, consecutive fusion reactions of tetrabenzocarbazole 2 through palladium-catalysed $\mathrm{C}-\mathrm{H} / \mathrm{C}-\mathrm{Cl}$ and $\mathrm{C}-\mathrm{H} / \mathrm{C}-\mathrm{Br}$ coupling achieve the synthesis of nitrogenembedded buckybowl 5, that is, 'azabuckybowl'28 under mild conditions. Owing to the electron-donating nature of the nitrogen atom, azabuckybowl 5 strongly interacts with $\mathrm{C}_{60}$ to furnish an inclusion complex, which exhibits a substantially high chargecarrier mobility in the solid state.

\section{Results}

Synthesis of nitrogen-embedded buckybowl. The synthesis of nitrogen-embedded buckybowl $\mathbf{5}$ started with the oxidative dimerization of 1 (Fig. 1) ${ }^{26}$. 9-Aminophenanthrene 1 was oxidized to tetrabenzocarbazole 2 in $94 \%$ yield. Reaction of $\mathbf{2}$ with $\mathrm{Pd}(\mathrm{OAc})_{2} /$ tricyclohexylphosphine provided singly fused product 3 in $63 \%$ yield $^{29}$. The twisted conformation of 3 was unambiguously elucidated by X-ray diffraction analysis (Supplementary Fig. 18). The bromination of 3 with bromine afforded tribrominated product 4 in $56 \%$ yield. Finally, the palladium-catalysed double $\mathrm{C}-\mathrm{H} / \mathrm{C}-\mathrm{Br}$ coupling furnished nitrogen-embedded buckybowl 5 in $46 \%$ yield. The proton nuclear magnetic resonance ( ${ }^{1} \mathrm{H}$ NMR) spectrum of $\mathbf{5}$ exhibited six proton signals in the aromatic region, indicating the formation of a fused and symmetrical molecule.

Structural elucidation and characteristics of azabuckybowl. The bowl-shaped structure of $\mathbf{5}$ was unambiguously elucidated by $\mathrm{X}$-ray diffraction (Fig. 2). In the crystal, one asymmetric unit contained two independent molecules of 5. The bowl depth, which is defined as the distance between the mean plane that consisted of five carbons at the edge and the centroid of the pyrrole ring, was 1.65 and $1.70 \AA$. The bowl depth of the central azacorannulene core was 0.90 and $0.92 \AA$, which is slightly greater

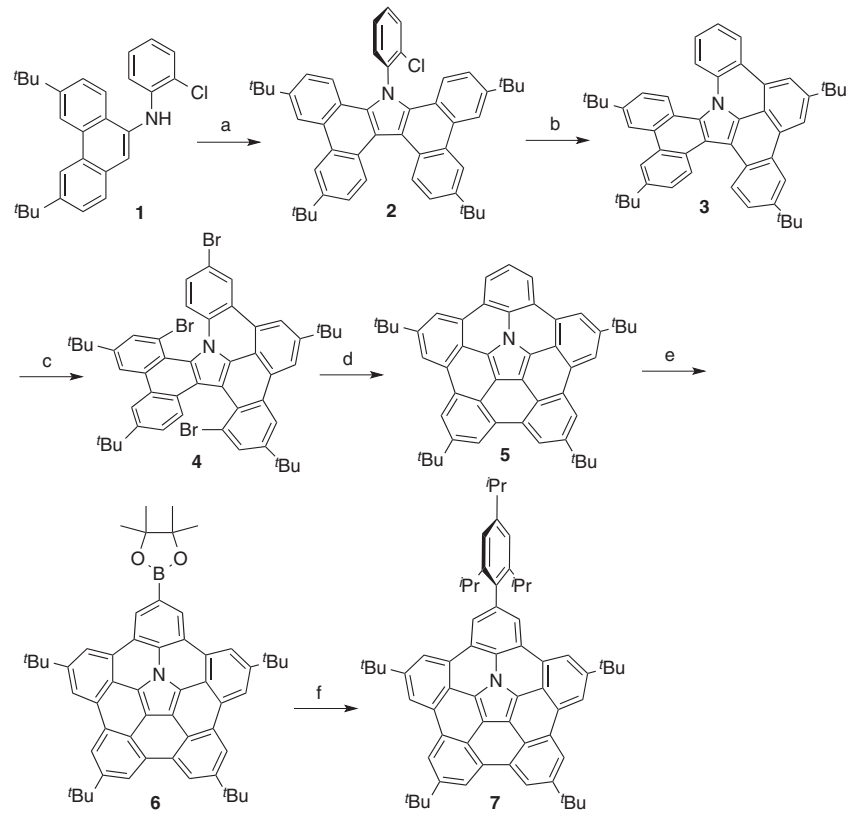

Figure 1 | Synthesis of nitrogen-embedded buckybowl 5 from

phenanthrene 1. Conditions: (a) 2,3-dichloro-5,6-dicyanobenzoquinone (DDQ), TFA, toluene, room temperature, $1 \mathrm{~h}, 94 \%$ yield. (b) $\mathrm{Pd}(\mathrm{OAc})_{2}$, $\mathrm{PCy}_{3} \cdot \mathrm{HBF}_{4}, \mathrm{~K}_{2} \mathrm{CO}_{3}, \mathrm{DMA}, 130{ }^{\circ} \mathrm{C}, 43 \mathrm{~h}, 63 \%$ yield. (c) $\mathrm{Br}_{2}, \mathrm{CCl}_{4}, 70^{\circ} \mathrm{C}$, $12.5 \mathrm{~h}, 56 \%$ yield. (d) $\mathrm{Pd}(\mathrm{OAc})_{2}, \mathrm{PCy}_{3} \cdot \mathrm{HBF}_{4}, \mathrm{~K}_{2} \mathrm{CO}_{3}, \mathrm{DMA}, 130^{\circ} \mathrm{C}, 16 \mathrm{~h}$ $46 \%$ yield. (e) bis(pinacolato)diboron, $[\operatorname{lr}(\mathrm{OMe}) \operatorname{cod}]_{2}, 4,4^{\prime}$-di-tert-butyl2,2'-bipyridyl, octane, $10.5 \mathrm{~h}, 110{ }^{\circ} \mathrm{C}, 80 \%$ yield. (f) 2 -bromo-1,3,5triisopropylbenzene, $\mathrm{PdCl}_{2}(\mathrm{dppf}) \bullet \mathrm{CH}_{2} \mathrm{Cl}_{2}, \mathrm{Cs}_{2} \mathrm{CO}_{3}, 1,4$-dioxane, $13 \mathrm{~h}$, $100^{\circ} \mathrm{C}, 55 \%$ yield.

than that of corannulene $(0.86 \AA)$. The curvature of 5 was further evaluated by Haddon's $\pi$-orbital axis vector (POAV) angles ${ }^{30}$. As shown in Fig. 2a, the POAV angles around the central pyrrole ring are in the range of $7.2^{\circ}-9.3^{\circ}$. These values are comparable with that of corannulene $\left(9.1^{\circ}\right)$. It is noteworthy that the molecules constructed a one-dimensional chain stacking structure in the crystal (Fig. 2c). Distances between the two closest molecules were 3.25 and $3.41 \AA$, indicating the existence of a $\pi-\pi$ interaction.

Bowl-to-bowl inversion of the azabuckybowl was investigated. Azabuckybowl 5 was further functionalized by iridium-catalysed $\mathrm{C}-\mathrm{H}$ borylation to provide 6 in $80 \%$ yield ${ }^{31,32}$. The SuzukiMiyaura cross-coupling reaction of $\mathbf{6}$ with 2-bromo-1,3,5triisopropylbenzene furnished the corresponding coupling product 7 in $55 \%$ yield. The ${ }^{1} \mathrm{H}$ NMR spectrum of 7 in 1,2-dichlorobenzene- $d_{4}$ at room temperature exhibited three doublet peaks for methyl protons of isopropyl groups at 1.43, 1.39 and 1.13 p.p.m. This non-symmetric feature indicates that 7 shows no bowl-to-bowl inversion at room temperature. As the temperature was raised, two proton signals at 1.43 and 1.13 p.p.m. were gradually broadened (Fig. 2d). Even at $170^{\circ} \mathrm{C}$, these signals were not coalesced. Accordingly, the bowl-to-bowl inversion energy $\left(\Delta G^{\ddagger}\right)$ was measured by two-dimensional exchange spectroscopy (2D EXSY) experiments. At $393 \mathrm{~K}, \Delta G^{\ddagger}$ was determined to be $23.3 \mathrm{kcal} \mathrm{mol}^{-1}$ in 1,2 -dichlorobenzene- $d_{4}$ (Supplementary Figs 32 and 33). This value is higher than that of the parent sumanene $\left(\Delta G^{\ddagger}=19.7-20.4 \mathrm{kcal} \mathrm{mol}^{-1}\right)^{33}$. The high bowl-inversion energy of 7 was also supported by theoretical calculations. The inversion barrier of 7 was calculated to be $19.9 \mathrm{kcal} \mathrm{mol}^{-1}$ by density functional theory (DFT) calculations at the B3LYP/cc-pVDZ level, which is higher than those of sumanene $\left(18.2 \mathrm{kcal} \mathrm{mol}^{-1}\right)$ and corannulene $\left(9.1 \mathrm{kcal} \mathrm{mol}^{-1}\right)$ calculated at the same level of theory ${ }^{34}$. 
a

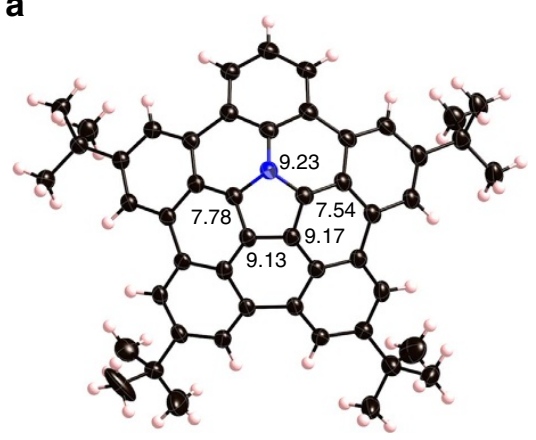

b

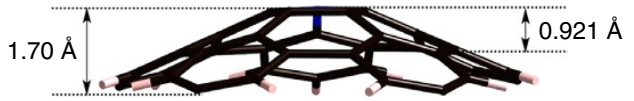

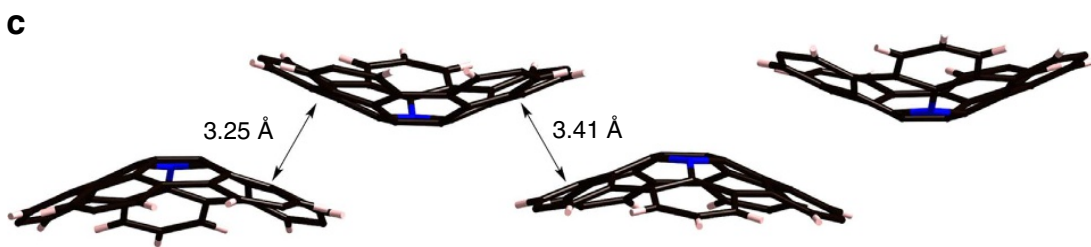

d
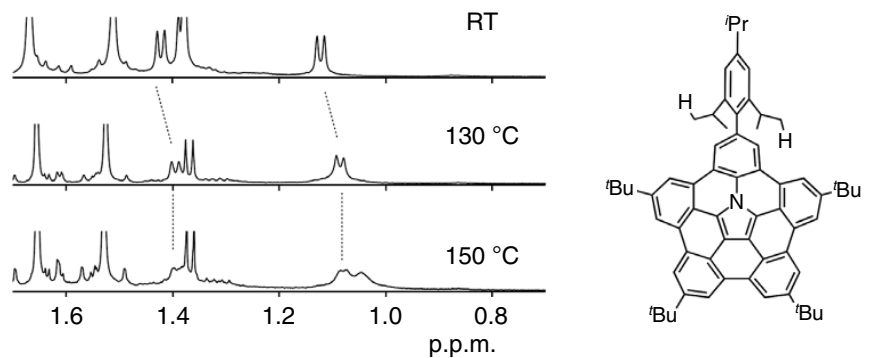

Figure 2 | Structural features of azabuckybowls. (a) Top view and POAV pyramidalization angles, (b) side view of $\mathbf{5}$ and (c) packing structure of $\mathbf{5}$ in the crystal. Thermal ellipsoids in a are scaled at 50\% probability level and $t$-butyl groups are omitted for clarity in $\mathbf{b}$ and $\mathbf{c}$. (d) Temperature-dependent NMR spectra of $\mathbf{7}$ in 1,2-dichlorobenzene- $d_{4}$. POAV angles and bowl depths in one of two molecules in the crystal are displayed in $\mathbf{a}$ and $\mathbf{b}$. Solvent molecules (o-xylene) in the crystal structure of $\mathbf{5}$ were omitted for clarity. RT, room temperature.

Optical and electrochemical properties of azabuckybowl. Figure 3 shows ultraviolet-visible absorption and emission spectra of 3 and 5 in $\mathrm{CH}_{2} \mathrm{Cl}_{2}$. The lowest energy bands shifted to the low-energy region as the degree of fusion increased. All compounds exhibited fluorescence in the visible region (Fig. 3b). The emission quantum yield of $\mathbf{5}$ was $17 \%$, which is the highest among buckybowls ${ }^{35}$. The Stokes shifts of $3\left(2,800 \mathrm{~cm}^{-1}\right)$ and 5 $\left(1,500 \mathrm{~cm}^{-1}\right)$ were relatively larger than that of a planar molecule. This reflects their excited state dynamics, owing to their distorted characteristics.

The electronic structures of $\mathbf{3}$ and $\mathbf{5}$ were further investigated by an electrochemical analysis (Supplementary Fig. 22 and Supplementary Table 2). Reversible oxidation waves were observed for all compounds. The first oxidation potentials were lowered in the order of $\mathbf{2}>\mathbf{3}>\mathbf{5}$, indicating effective electron donation from the nitrogen atom to the entire $\pi$ system.

We then examined the protonation behaviour of $\mathbf{5}$, because 5 was expected to have higher basicity than planar amines. The addition of trifluoroacetic acid (TFA) to a dichloromethane solution of 5 induced a dramatic change in its absorption spectrum (Fig. 3c). Interestingly, the same change was observed on the addition of a one-electron oxidant, tris(4-bromophenyl) aminium hexachloroantimonate (BAHA) (Fig. 3d). We also monitored the electro-oxidative absorption spectrum of $\mathbf{5}$ in $\mathrm{CH}_{2} \mathrm{Cl}_{2}$, which exhibited essentially the same change (Fig. 3e). These facts strongly indicate that the addition of TFA resulted in the generation of the radical cation species rather than simple protonation. The formation of the radical cation was confirmed by electron spin resonance (ESR) measurements (Supplementary
Fig. 26). The solution of 5 in the presence of TFA exhibited a distinct signal at $g=2.002$, as was the case of the oxidation of $\mathbf{5}$ with BAHA. The conversion of $\mathbf{5}$ to the radical cation was almost quantitative under air atmosphere but was substantially lower under argon (Supplementary Fig. 27). The radical cation generation is likely due to electron transfer between $\mathbf{5}$ and protonated 5 involving air oxidation ${ }^{36}$. The facile generation of the radical cation from 5 would allow the investigation of the effect of oxidative doping on solid-state properties. This phenomenon also implies that nitrogen-doped electron-rich nanocarbons may undergo a similar radical cation generation by protonation.

Association behaviour of 5 with $\mathbf{C}_{\mathbf{6 0}}$. The effect of nitrogen also appeared in the association behaviour of 5 with $\mathrm{C}_{60}$. For hydrocarbon buckybowls, their association constants with $\mathrm{C}_{60}$ were very low to be measured ${ }^{37-40}$. The incorporation of electron-rich nitrogen in buckybowls should enable tighter binding with electron-deficient fullerenes. The electrochemical analysis revealed its much lower oxidation potential $(0.20 \mathrm{~V})$ when compared with corannulene $(1.57 \mathrm{~V})$ (Fig. $3 \mathrm{f})^{41}$. The addition of $\mathrm{C}_{60}$ into an 1,2-dichlorobenzene solution of 5 induced a change in the ultraviolet-visible absorption and emission spectra (Fig. 4b,c). In particular, the appearance of broad absorption bands in the near-infrared region suggests intermolecular charge-transfer interactions between 5 and $\mathrm{C}_{60}$. The association behaviour was also monitored by ${ }^{1} \mathrm{H}$ NMR analysis. On the addition of $\mathrm{C}_{60}$ into a toluene- $d_{8}$ solution of 5 , all aromatic proton signals were upfield 
a

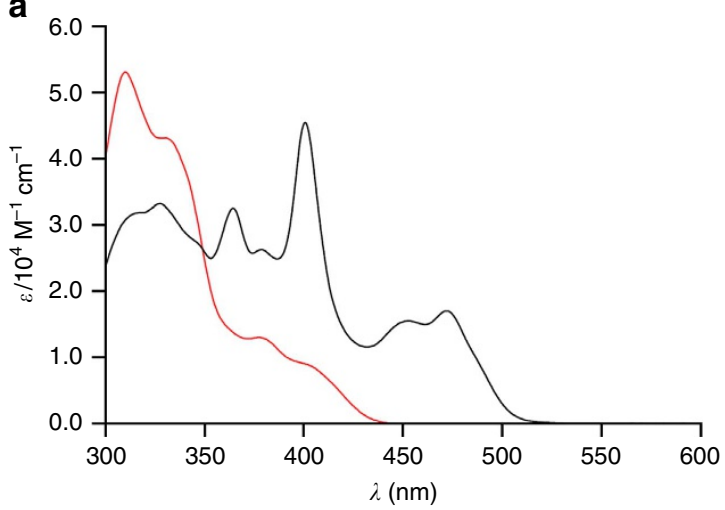

C

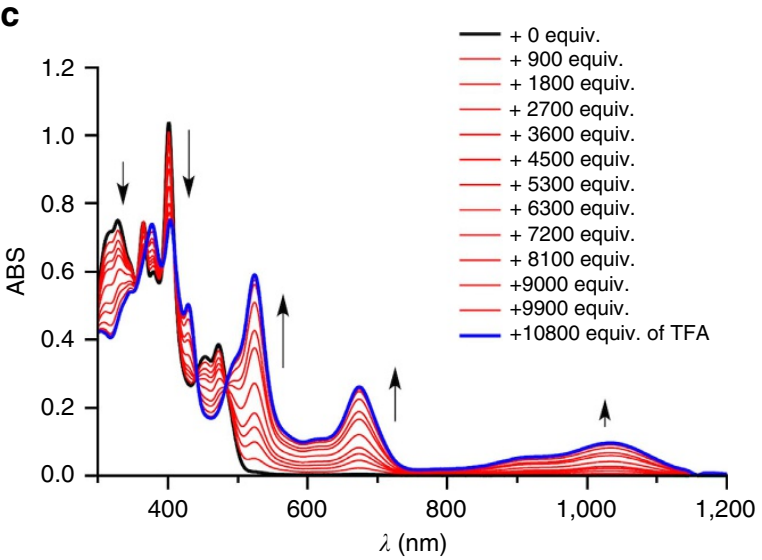

e

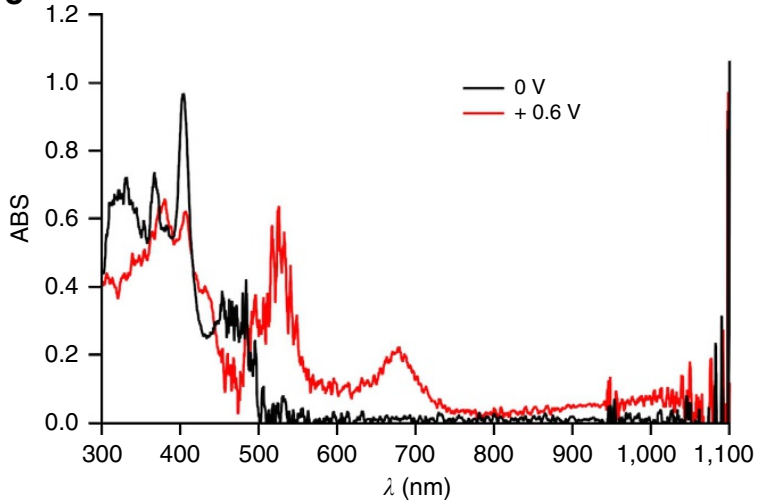

b

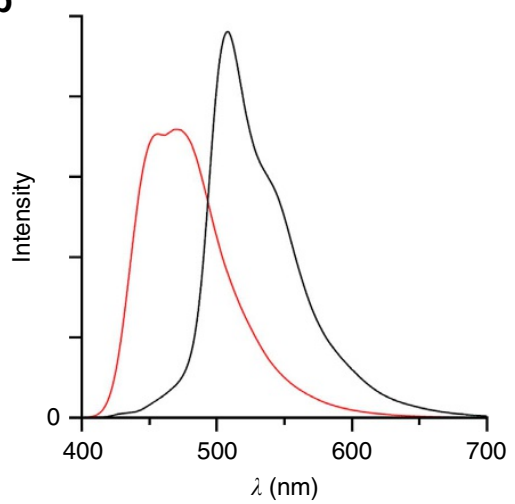

d

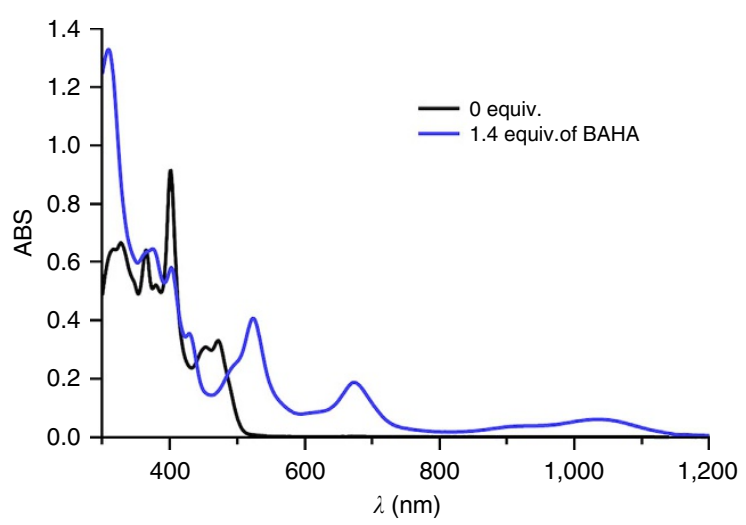

f

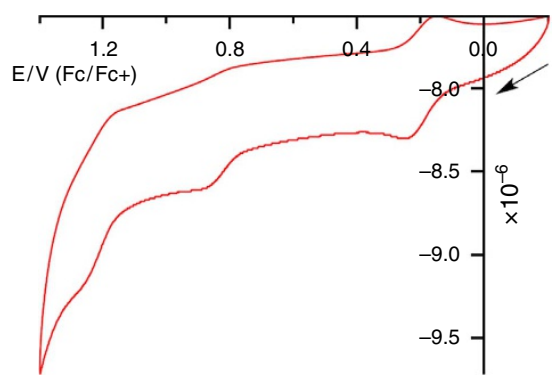

Figure 3 | Physical properties of 5. (a) Ultraviolet-visible absorption spectra in $\mathrm{CH}_{2} \mathrm{Cl}_{2}$ and (b) emission spectra of 3 (red) and $\mathbf{5}$ (black) in $\mathrm{CH}_{2} \mathrm{Cl}_{2}$ (concentration: $7.6 \times 10^{-7} \mathrm{M}$ ). (c) Spectral changes in absorption spectra of $\mathbf{5}$ on the addition of TFA into a dichloromethane solution of $\mathbf{5}$. (d) Absorption spectra of $\mathbf{5}$ in $\mathrm{CH}_{2} \mathrm{Cl}_{2}$ before and after the addition of 1.4 equiv. of BAHA. (e) Spectroelectrochemical analysis of $\mathbf{5}$ in $\mathrm{CH}_{2} \mathrm{Cl}_{2}$. (f) $\mathrm{Cyclic}$ voltammogram of 5 measured in $\mathrm{CH}_{2} \mathrm{Cl}_{2}$ with tetra-n-butylammonium hexafluorophosphate as the electrolyte.

shifted (Fig. 4a). This indicates that 5 and $\mathrm{C}_{60}$ interacted in a convex-concave manner. This was revealed by the $\mathrm{X}$-ray crystallographic analysis and showed that $\mathrm{C}_{60}$ was located above the centre of 5 (Fig. $4 \mathrm{~d}, \mathrm{e}$ ). The penetration depth of $\mathrm{C}_{60}$ into 5 measured from the centroid of the pyrrole ring to the centroid of $\mathrm{C}_{60}$ is $6.82 \AA$, and that measured from the shortest distance from the concave surface of 5 to a $\mathrm{C}_{60}$ surface is $3.29 \AA$, whereas the depths of $\mathrm{C}_{60}$ into the corannulene/ $\mathrm{C}_{60}$ complex are 6.94 and 3.75 $\AA$. The short distance between 5 and $\mathrm{C}_{60}$ indicates the presence of attractive interactions between them. Judging from the relatively long distance $(>3.74 \AA)$, the $\mathrm{CH}-\pi$ interaction between tert-butyl groups and $\mathrm{C}_{60}$ was not essential. The binding constant was determined to be $3,800 \mathrm{M}^{-1}$ by titration with absorption and fluorescence spectra (Supplementary Figs 23-25).
This value is approximately three times larger than that of perthiolated corannulene. The existence of intermolecular chargetransfer interactions between 5 and $\mathrm{C}_{60}$ was indicated by the quenching behaviour of the emission on the addition of $\mathrm{C}_{60}$ to a 1,2-dichlorobenzene solution of $\mathbf{5}$ (Fig. 4c). The DFT optimization of $\mathbf{5} \supset \mathbf{C}_{\mathbf{6 0}}$ afforded nearly the same structure as the crystal structure. The highest occupied molecular orbital was spread over the entire surface of $\mathbf{5}$, whereas the lowest unoccupied molecular orbital was delocalized on $\mathrm{C}_{60}$ (Supplementary Fig. 29). In addition, oscillator strengths of the absorption of $\mathbf{5} \supset \mathbf{C}_{\mathbf{6 0}}$ were simulated by the time-dependent DFT method (Supplementary Fig. 30). The broad lowest-energy band in the near-infrared region was assigned as the highest occupied molecular orbitallowest unoccupied molecular orbital transition. These results 
a

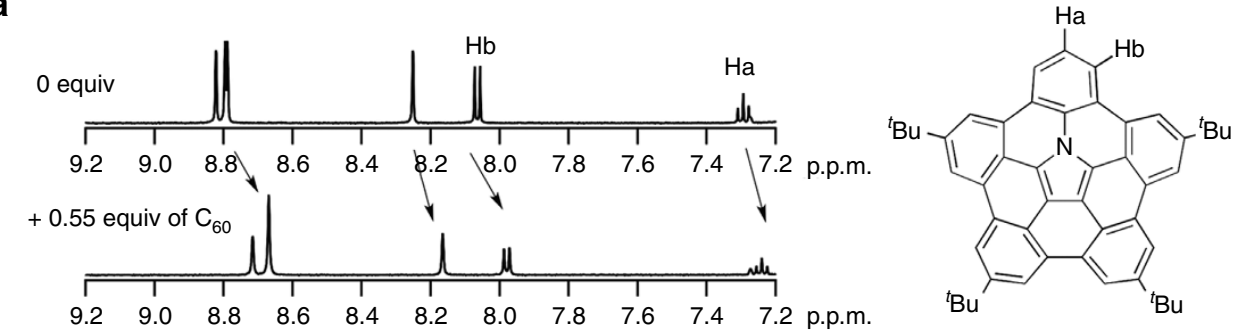

b

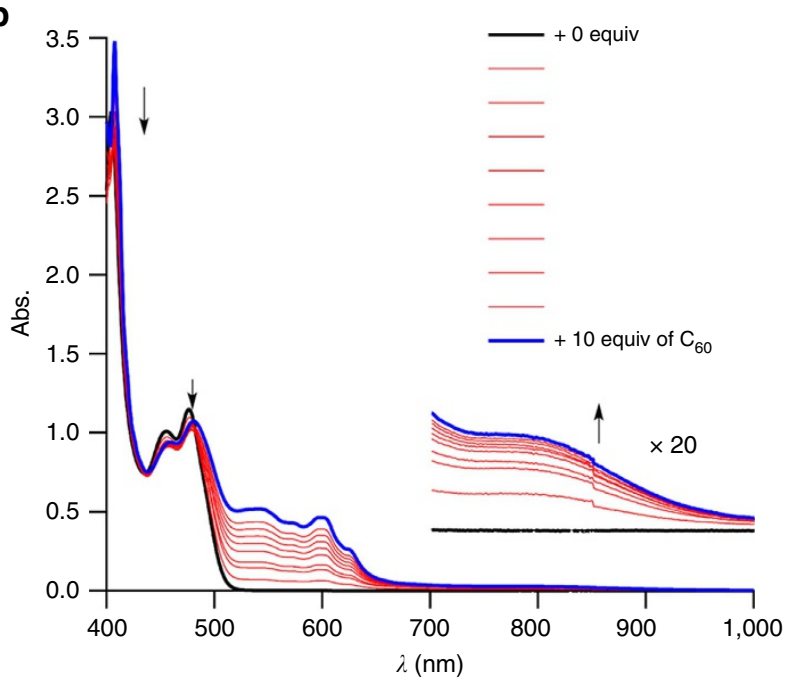

d

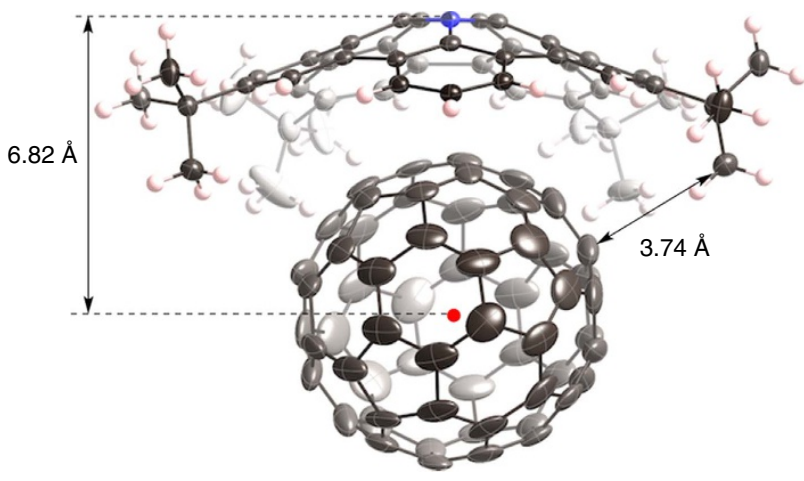

C

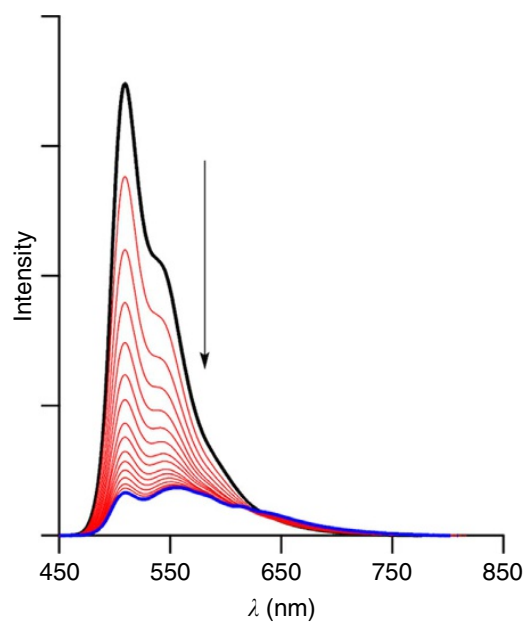

e

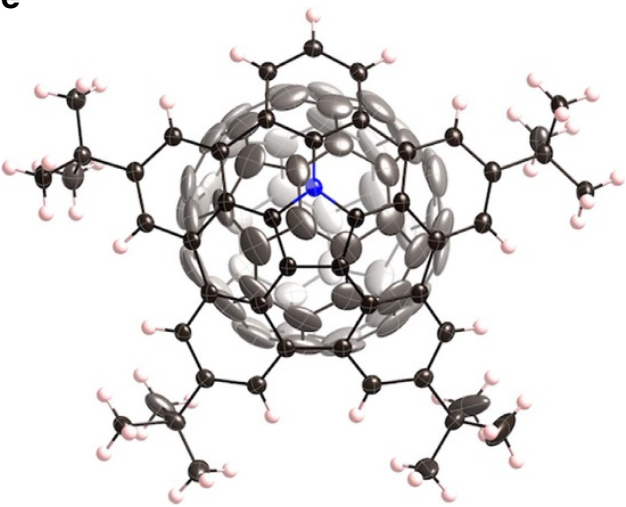

Figure 4 | $\mathbf{C}_{60}$ binding behaviour of 5 in solution and solid. (a) ${ }^{1} \mathrm{H}$ NMR spectra before (top) and after (bottom) addition of 0.55 equiv. of $\mathrm{C}_{60}$ into a toluene- $d_{8}$ solution of $\mathbf{5}$. (b) Ultraviolet-visible absorption spectra of addition of 0-10 equiv. of $C_{60}$ into a 1,2-dichlorobenzene solution of $\mathbf{5}$.

(c) Fluorescence spectra of addition from 0-150 equiv. of $\mathrm{C}_{60}$ into a 1,2-dichlorobenzene solution of $\mathbf{5}$. (d) Side view and (e) top view of $X$-ray crystal structure of $\mathbf{5} \supset \mathbf{C}_{\mathbf{6 0}}$. Thermal ellipsoids are scaled at $50 \%$ probability level. Solvent molecules (toluene) in the crystal structure of $\mathbf{5} \supset \mathbf{C}_{\mathbf{6 0}}$ were omitted for clarity.

supported the conclusion that an intermolecular charge-transfer interaction exists between 5 and $\mathrm{C}_{60}$.

Finally, we investigated the effect of the association with $\mathrm{C}_{60}$ of $\mathbf{5}$ on the charge-carrier mobility of $\mathbf{5}$ by flash-photolysis time-resolved microwave conductivity (FP-TRMC) measurements ${ }^{42}$. The maximum transient conductivity $(\phi \Sigma \mu)$ of 5 was measured to be $1.5 \times 10^{-5} \mathrm{~cm}^{2} \mathrm{~V}^{-1} \mathrm{~s}^{-1}$ (Supplementary Fig. 28). For the co-crystal of $\mathbf{5} \supset \mathbf{C}_{\mathbf{6 0}}$, the mobility was enhanced to $2.4 \times 10^{-4} \mathrm{~cm}^{2} \mathrm{~V}^{-1} \mathrm{~s}^{-1}$ (Fig. 5a,b). The chargecarrier generation efficiency $(\phi)$ was determined to be $4.4 \times 10^{-3}$ by the transient absorption spectroscopy measurement. Accordingly, the local charge mobility of $\mathbf{5} \supset \mathbf{C}_{\mathbf{6 0}}$ was $0.17 \mathrm{~cm}^{2} \mathrm{~V}^{-1} \mathrm{~s}^{-1}$. Such a large mobility of $\mathbf{5} \supset \mathbf{C}_{\mathbf{6 0}}$ should originate from effective charge separation caused by an electronic interaction between 5 and $\mathrm{C}_{60}$. Furthermore, the alignment of $\mathbf{5}$ and $\mathrm{C}_{60}$ in the co-crystal may contribute to mobility enhancement. Both $\mathrm{C}_{60}$ and 5 construct one-dimensional chain alignments in the co-crystal (Fig. 5c).

\section{Discussion}

In summary, we have achieved the synthesis of a nitrogenembedded buckybowl under mild conditions. The total yield of azabuckybowl $\mathbf{5}$ was 11\% from 9-bromophenanthrene. We also found that the protonation of $\mathbf{5}$ resulted in the efficient generation of radical cation species. The nitrogen-embedded buckybowl was sufficiently electron-rich to assemble tightly with $\mathrm{C}_{60}$ in solution and solid states. The molecular assembly of 5 with $\mathrm{C}_{60}$ exhibited a significantly high charge mobility $\left(0.17 \mathrm{~cm}^{2} \mathrm{~V}^{-1} \mathrm{~s}^{-1}\right)$. The nitrogen-embedded buckybowl can be a novel molecular entity 

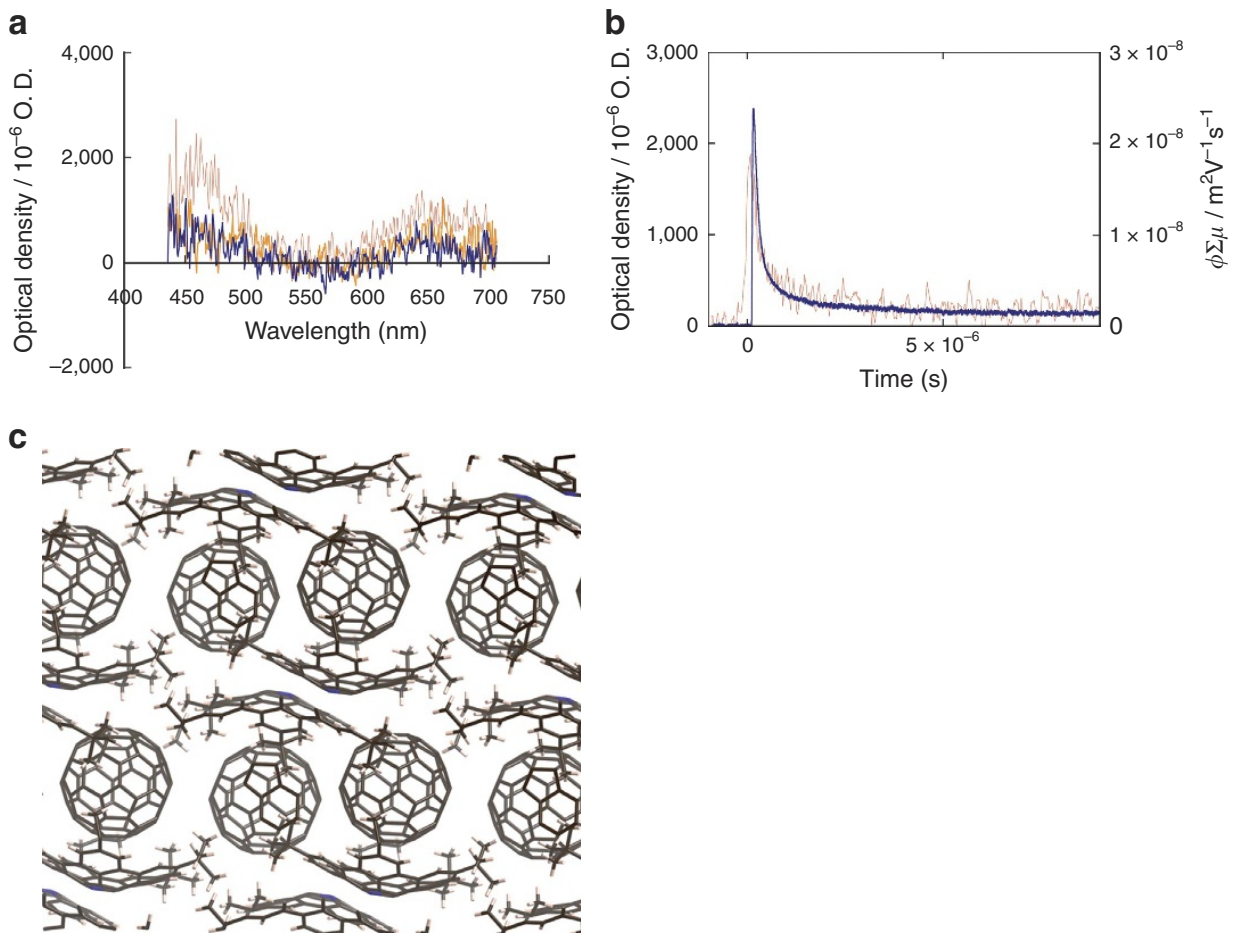

Figure $\mathbf{5}$ | Charge-carrier mobility of $\mathbf{5} \supset \mathbf{C}_{\mathbf{6 0}}$. (a) Transient absorption spectra of $\mathbf{5} \supset \mathbf{C}_{\mathbf{6 0}}$ on exposure to $355 \mathrm{~nm}$ laser pulses at $3.8 \times 10^{16}$ photons per $\mathrm{cm}^{2}$. Spectra wire observed immediately after pulse exposure (red), $2 \mathrm{~ms}$ (orange) and $7 \mathrm{~ms}$ (blue) after pulse exposure. All spectra were recorded at room temperature under air-saturated atmosphere. (b) Kinetic traces of a photoconductivity transient (blue) recorded by FP-TRMC measurements and transient optical absorption at $650 \mathrm{~nm}$ for $\mathbf{5} \supset \mathbf{C}_{\mathbf{6 0}}$ on exposure to $355 \mathrm{~nm}$ laser pulses at $9.1 \times 10^{15}$ photons per $\mathrm{cm}^{2}$ (conductivity) and $3.8 \times 10^{16}$ photons per $\mathrm{cm}^{2}$ (optical). (c) Side view of crystal packing of $\mathbf{5} \supset \mathbf{C}_{\mathbf{6 0}}$. Solvent molecules (toluene) were omitted for clarity.

in the field of curved $\pi$ systems as fullerene hosts, anisotropic $\pi$ donors and precursors to nitrogen-containing nanocarbon materials.

\section{Method \\ Materials and characterization. ${ }^{1} \mathrm{H}$ NMR $(500 \mathrm{MHz})$ and ${ }^{13} \mathrm{C}$ NMR $(126 \mathrm{MHz})$ spectra were recorded using a Bruker AVANCE III HD spectrometer. Chemical shifts were reported at the delta scale in p.p.m. relative to $\mathrm{CHCl}_{3}(\delta=7.260$ p.p.m.), $\mathrm{CH}_{2} \mathrm{Cl}_{2}$ ( $\delta=5.320$ p.p.m.), toluene- $d_{8}(\delta=7.000$ p.p.m. $)$, acetone- $d_{6}(\delta=2.05$ p.p.m.) and 1,2-dichlorobenzene- $d_{4}\left(\delta=6.930\right.$ p.p.m.) for ${ }^{1} \mathrm{H}$ NMR and $\mathrm{CDCl}_{3}$ $(\delta=77.0$ p.p.m. $)$ for ${ }^{13} \mathrm{C}$ NMR. ${ }^{1} \mathrm{H}$ and ${ }^{13} \mathrm{C}$ NMR spectra are provided for all compounds; see Supplementary Figs 1-17. Ultraviolet-visible-near infrared absorption spectra were recorded using a Shimadzu UV-2550 or JASCO V670 spectrometer. Emission spectra were recorded using a JASCO FP-6500 spectro- meter and absolute fluorescence quantum yields were measured by the photon- counting method using an integration sphere. Mass spectra were recorded using a Bruker microTOF by electrospray ionization (ESI) methods. Unless otherwise noted, materials obtained from commercial suppliers were used without further purification.}

Synthesis of 3,6-Di-tert-butyl-9-bromophenanthrene. 3,6-Di-tert-butylphenanthrene $(0.540 \mathrm{~g}, 1.86 \mathrm{mmol})$ was dissolved in $\mathrm{CCl}_{4}(11 \mathrm{ml})$ in a two-necked flask equipped with a dropping funnel. $\mathrm{Br}_{2}(0.10 \mathrm{ml}, 1.95 \mathrm{mmol})$ and $\mathrm{CCl}_{4}(11 \mathrm{ml})$ were added into the dropping funnel. The solution was heated to $50^{\circ} \mathrm{C}$ and then the bromine solution was added slowly over $1 \mathrm{~h}$. After the addition was completed, the mixture was stirred for additional $30 \mathrm{~min}$. The reaction mixture was cooled to room temperature and then quenched with aqueous $\mathrm{Na}_{2} \mathrm{~S}_{2} \mathrm{O}_{3}$. The resulting mixture was extracted with $\mathrm{CH}_{2} \mathrm{Cl}_{2}$ and the organic layer was washed with aqueous $\mathrm{Na}_{2} \mathrm{~S}_{2} \mathrm{O}_{3}$, dried over $\mathrm{Na}_{2} \mathrm{SO}_{4}$ and concentrated in vacuo. Purification by silica-gel column chromatography (cyclohexane as eluent) afforded the title compound $(0.645 \mathrm{~g}, 1.75 \mathrm{mmol})$ in $94 \%$ yield as a white solid. ${ }^{1} \mathrm{H}$ NMR $(500 \mathrm{MHz})$ $\left(\mathrm{CDCl}_{3}\right): \delta=8.70(\mathrm{~d}, J=1.5 \mathrm{~Hz}, 1 \mathrm{H}), 8.66(\mathrm{~s}, 1 \mathrm{H}), 8.30(\mathrm{~d}, J=8.5 \mathrm{~Hz}, 1 \mathrm{H}), 8.02$ $(\mathrm{s}, 1 \mathrm{H}), 7.77\left(\mathrm{dd}, J_{1}=8.5 \mathrm{~Hz}, J_{2}=1.5 \mathrm{~Hz}, 1 \mathrm{H}\right), 7.74(\mathrm{~d}, J=8.5 \mathrm{~Hz}, 1 \mathrm{H}), 7.68(\mathrm{dd}$, $\left.J_{1}=8.5 \mathrm{~Hz}, J_{2}=1.5 \mathrm{~Hz}, 1 \mathrm{H}\right), 1.53(\mathrm{~s}, 9 \mathrm{H}), 1.52(\mathrm{~s}, 9 \mathrm{H})$ p.p.m.; ${ }^{13} \mathrm{C}$ NMR $(126 \mathrm{MHz})$ $\left(\mathrm{CDCl}_{3}\right): \delta=150.0,149.6,131.1,130.4,129.5,129.3,128.5,127.8,127.5,125.6$, $125.4,120.7,118.2,118.1,35.25,35.14,31.42$ p.p.m.; high-resolution atmospheric pressure chemical ionization-MS (APCI-MS): $m / z=368.1124$, calcd for $\left(\mathrm{C}_{22} \mathrm{H}_{25} \mathrm{Br}\right)^{+}=368.1134\left[M^{+}\right]$.
Synthesis of compound 1. A Schlenk tube containing 3,6-di-tert-butyl-9-bromophenanthrene $(0.200 \mathrm{~g}, 0.542 \mathrm{mmol}), \mathrm{Cs}_{2} \mathrm{CO}_{3}(0.265 \mathrm{~g}, 0.812 \mathrm{mmol})$, $\mathrm{Pd}_{2} \mathrm{dba}_{3} \cdot \mathrm{CHCl}_{3}(28.0 \mathrm{mg}, 27.1 \mu \mathrm{mol})$ and Xantphos $(31.3 \mathrm{mg}, 54.0 \mu \mathrm{mol})$ was flushed with $\mathrm{N}_{2}$ three times. To the tube, 2-chloroaniline $(86 \mu \mathrm{l}, 0.812 \mathrm{mmol})$ and dry 1,4-dioxane $(2.0 \mathrm{ml})$ were added. The mixture was stirred for $46 \mathrm{~h}$ at $100^{\circ} \mathrm{C}$. The resulting mixture was cooled to room temperature, passed through a pad of Celite and concentrated in vacuo. Purification by silica-gel column chromatography (hexane/ $\left.\mathrm{CH}_{2} \mathrm{Cl}_{2}\right)$ afforded $\mathbf{1}(0.158 \mathrm{~g}, 0.380 \mathrm{mmol})$ in $70 \%$ yield as a pale yellow solid. ${ }^{1} \mathrm{H}$ NMR $(500 \mathrm{MHz})\left(\mathrm{CDCl}_{3}\right): \delta=8.76(\mathrm{~d}, J=2.0 \mathrm{~Hz}, 1 \mathrm{H}), 8.68$ $(\mathrm{d}, J=1.0 \mathrm{~Hz}, 1 \mathrm{H}), 8.04(\mathrm{~d}, J=8.5 \mathrm{~Hz}, 1 \mathrm{H}), 7.74(\mathrm{~d}, J=8.5 \mathrm{~Hz}, 1 \mathrm{H}), 7.69$ $\left(\right.$ dd, $\left.J_{1}=8.5 \mathrm{~Hz}, J_{2}=2.0 \mathrm{~Hz}, 1 \mathrm{H}\right), 7.66\left(\mathrm{dd}, J_{1}=8.5 \mathrm{~Hz}, J_{2}=1.5 \mathrm{~Hz}, 1 \mathrm{H}\right), 7.61$ (s, $1 \mathrm{H}), 7.41\left(\mathrm{dd}, J_{1}=8.0 \mathrm{~Hz}, J_{2}=1.5 \mathrm{~Hz}, 1 \mathrm{H}\right), 7.04\left(\mathrm{ddd}, J_{1}=8.5 \mathrm{~Hz}, J_{2}=7.0 \mathrm{~Hz}\right.$, $\left.J_{3}=1.5 \mathrm{~Hz}, 1 \mathrm{H}\right), 6.88\left(\mathrm{dd}, J_{1}=8.5 \mathrm{~Hz}, J_{2}=1.5 \mathrm{~Hz}, 1 \mathrm{H}\right), 6.77\left(\mathrm{ddd}, J_{1}=J_{2}=8.0 \mathrm{~Hz}\right.$, $\left.J_{3}=1.5 \mathrm{~Hz}, 1 \mathrm{H}\right), 6.36(\mathrm{~s}, 1 \mathrm{H}), 1.53(\mathrm{~s}, 9 \mathrm{H}), 1.52(\mathrm{~s}, 9 \mathrm{H})$ p.p.m.; ${ }^{13} \mathrm{C}$ NMR $(126 \mathrm{MHz})\left(\mathrm{CDCl}_{3}\right): \delta=149.6,148.6,142.4,134.6,131.4,130.2,129.5,128.5,127.7$, 127.6, 127.1, 125.1, 125.0, 122.8, 120.5, 119.4, 118.9, 118.6, 117.9, 115.6, 35.18, 31.54, 31.48 p.p.m.; high-resolution APCI-MS: $m / z=416.2141$, calcd for $\left(\mathrm{C}_{28} \mathrm{H}_{31} \mathrm{ClN}\right)^{+}=416.2140\left[(M+H)^{+}\right]$.

Synthesis of compound 2. A flask-containing compound $\mathbf{1}(0.100 \mathrm{~g}, 0.241 \mathrm{mmol})$ was flushed with $\mathrm{N}_{2}$ three times. To the flask, a dry and degassed toluene/ $\mathrm{CF}_{3} \mathrm{COOH}(10 \mathrm{ml}, 33 \mu \mathrm{l})$ solution was added. To the solution, a solution of DDQ $(0.109 \mathrm{~g}, 0.482 \mathrm{mmol})$ in dry and degassed toluene $/ \mathrm{CF}_{3} \mathrm{COOH}(10 \mathrm{ml}, 33 \mu \mathrm{l})$ was added and the mixture was stirred for $1 \mathrm{~h}$ at room temperature. The reaction mixture was quenched with aqueous $\mathrm{NaHCO}_{3}$ and aqueous $\mathrm{Na}_{2} \mathrm{~S}_{2} \mathrm{O}_{3}$, and extracted with $\mathrm{CH}_{2} \mathrm{Cl}_{2}$. The organic layer was washed with water, dried over $\mathrm{Na}_{2} \mathrm{SO}_{4}$ and concentrated in vacuo. Purification by silica-gel column chromatography (hexane/ $\mathrm{CH}_{2} \mathrm{Cl}_{2}$ ) afforded compound $2(79.6 \mathrm{mg}, 0.113 \mathrm{mmol})$ in $94 \%$ yield as a pale yellow solid. ${ }^{1} \mathrm{H}$ NMR $(500 \mathrm{MHz})\left(\mathrm{CDCl}_{3}\right): \delta=9.00(\mathrm{~d}, J=8.5 \mathrm{~Hz}, 2 \mathrm{H}), 8.80(\mathrm{~d}, J=1.5$ $\mathrm{Hz}, 2 \mathrm{H}), 8.75(\mathrm{~d}, J=1.5 \mathrm{~Hz}, 2 \mathrm{H}), 7.85\left(\mathrm{dd}, J_{1}=8.5 \mathrm{~Hz}, J_{2}=1.5 \mathrm{~Hz}, 1 \mathrm{H}\right), 7.69-7.77$ $(\mathrm{m}, 4 \mathrm{H}), 7.62\left(\mathrm{ddd}, J_{1}=J_{2}=7.5 \mathrm{~Hz}, J_{3}=1.5 \mathrm{~Hz}, 1 \mathrm{H}\right), 7.32\left(\mathrm{dd}, J_{1}=9.0 \mathrm{~Hz}\right.$, $\left.J_{2}=1.5 \mathrm{~Hz}, 2 \mathrm{H}\right), 7.08(\mathrm{~d}, J=9.0 \mathrm{~Hz}, 2 \mathrm{H}), 1.58(\mathrm{~s}, 18 \mathrm{H}), 1.48$ (s, 18H) p.p.m.; ${ }^{13} \mathrm{C}$ $\operatorname{NMR}(126 \mathrm{MHz})\left(\mathrm{CDCl}_{3}\right): \delta=147.3,146.8,140.7,135.7,132.6,132.2,131.3,131.1$ 130.6, 128.9, 127.8, 126.6, 125.8, 124.4, 123.6, 121.7, 120.5, 119.7, 119.4, 116.5, 35.02, $34.91,31.61,31.40$ p.p.m.; ultraviolet-visible $\left(\mathrm{CH}_{2} \mathrm{Cl}_{2}\right): \lambda_{\max }\left(\varepsilon\left[\mathrm{M}^{-1} \mathrm{~cm}^{-1}\right]\right)=342$ (22,000), 359 (23,000), $376(21,000) \mathrm{nm}$; high-resolution APCI-MS: $\mathrm{m} / \mathrm{z}=702.3872$, calcd for $\left(\mathrm{C}_{50} \mathrm{H}_{53} \mathrm{ClN}\right)^{+}=702.3861\left[(M+H)^{+}\right]$.

Synthesis of compound 3. A Schlenk tube containing compound $2(30.1 \mathrm{mg}$, $42.8 \mu \mathrm{mol}), \mathrm{K}_{2} \mathrm{CO}_{3}(35.5 \mathrm{mg}, 0.257 \mathrm{mmol}), \mathrm{Pd}(\mathrm{OAc})_{2}(9.56 \mathrm{mg}, 42.6 \mu \mathrm{mol})$ and 
$\mathrm{PCy}_{3} \cdot \mathrm{HBF}_{4}(31.5 \mathrm{mg}, 85.5 \mu \mathrm{mol})$ was flushed with $\mathrm{N}_{2}$ three times. To the tube, dry and degassed DMA $(1.5 \mathrm{ml})$ was added. The mixture was stirred for $43 \mathrm{~h}$ at $130{ }^{\circ} \mathrm{C}$. The resulting mixture was cooled to room temperature, passed through a pad of Celite and concentrated in vacuo. Purification by silica-gel column chromatography (hexane $/ \mathrm{CH}_{2} \mathrm{Cl}_{2}$ ) afforded compound $3(17.8 \mathrm{mg}, 26.8 \mu \mathrm{mol})$ in $63 \%$ yield as a yellow solid. ${ }^{1} \mathrm{H}$ NMR $(500 \mathrm{MHz})\left(\mathrm{CDCl}_{3}\right): \delta=9.15(\mathrm{~d}, J=9.0 \mathrm{~Hz}, 1 \mathrm{H}), 9.13$ $(\mathrm{d}, J=10 \mathrm{~Hz}, 1 \mathrm{H}) 8.92(\mathrm{~d}, J=1.0 \mathrm{~Hz}, 1 \mathrm{H}), 8.89(\mathrm{~s}, 1 \mathrm{H}), 8.86(\mathrm{~d}, J=0.5 \mathrm{~Hz}, 1 \mathrm{H})$, $8.83(\mathrm{~d}, J=0.5 \mathrm{~Hz}, 1 \mathrm{H}), 8.61\left(\mathrm{dd}, J_{1}=8.0 \mathrm{~Hz}, J_{2}=1.5 \mathrm{~Hz}, 1 \mathrm{H}\right), 8.59(\mathrm{~s}, 1 \mathrm{H}), 8.51$ $(\mathrm{d}, J=8.5 \mathrm{~Hz}, 1 \mathrm{H}), 8.40(\mathrm{~d}, J=8.0 \mathrm{~Hz}, 1 \mathrm{H}), 7.88(\mathrm{~d}, J=8.5 \mathrm{~Hz}, 1 \mathrm{H}), 7.84$ $(\mathrm{d}, J=8.5 \mathrm{~Hz}, 1 \mathrm{H}), 7.66\left(\mathrm{dd}, J_{1}=8.5 \mathrm{~Hz}, J_{2}=1.5 \mathrm{~Hz}, 1 \mathrm{H}\right), 7.50-7.56(\mathrm{~m}, 2 \mathrm{H}), 1.71$ (s, 9H), 1.64 (s, 9H), 1.63 (s, 9H), 1.60 (s, 9H) p.p.m.; ${ }^{13} \mathrm{C}$ NMR $(126 \mathrm{MHz})$ $\left(\mathrm{CDCl}_{3}\right): \delta=148.9,147.7,147.7,146.5,135.2,132.2,129.3,129.1,129.0,128.9$ $127.5,127.3,127.2,126.9,126.6,126.1,125.4,124.7,124.6,124.2,124.2,124.0$ $123.4,123.1,122.8,121.9,120.1,119.7,119.6,119.5,118.4,118.1,116.0,110.8$ $35.84,35.12,35.10,35.01,32.00,31.65,31.64,31.56$ p.p.m.; ultraviolet-visible $\left(\mathrm{CH}_{2} \mathrm{Cl}_{2}\right): \lambda_{\max }\left(\varepsilon\left[\mathrm{M}^{-1} \mathrm{~cm}^{-1}\right]\right)=310(53,000), 330(43,000), 378(13,000)$ and $404(8,700) \mathrm{nm}$; fluorescence $\left(\mathrm{CH}_{2} \mathrm{Cl}_{2}, \lambda_{\mathrm{ex}}=378 \mathrm{~nm}\right): \lambda_{\mathrm{em}}=456$ and $471 \mathrm{~nm}\left(\Phi_{\mathrm{f}}=0.18\right)$; high-resolution APCI-MS: $m / z=666.4088$, calcd for $\left(\mathrm{C}_{50} \mathrm{H}_{52} \mathrm{~N}\right)^{+}=666.4094\left[(M+H)^{+}\right]$.

Synthesis of compound 4. Compound 3 ( $40.1 \mathrm{mg}, 60.3 \mu \mathrm{mol}$ ) was dissolved in $\mathrm{CCl}_{4}(6.0 \mathrm{ml})$ in a two-necked flask equipped with a dropping funnel. A solution of $\mathrm{Br}_{2}(0.10 \mathrm{ml}, 2.0 \mathrm{mmol})$ in $\mathrm{CCl}_{4}(3.0 \mathrm{ml})$ was added to the dropping funnel. The mixture was heated to $70^{\circ} \mathrm{C}$ and then the bromine solution was added slowly over $15 \mathrm{~min}$. After the addition was complete, the mixture was stirred for an additional $12.5 \mathrm{~h}$. The reaction mixture was cooled to room temperature and then quenched with aqueous $\mathrm{Na}_{2} \mathrm{~S}_{2} \mathrm{O}_{3}$. The resulting mixture was extracted with $\mathrm{CH}_{2} \mathrm{Cl}_{2}$ and the organic layer was washed with aqueous $\mathrm{Na}_{2} \mathrm{~S}_{2} \mathrm{O}_{3}$, dried over $\mathrm{Na}_{2} \mathrm{SO}_{4}$ and concentrated in vacuo. Purification by silica-gel column chromatography (hexane only) afforded compound $4(30.3 \mathrm{mg}, 33.6 \mu \mathrm{mol})$ in $56 \%$ yield as a yellow solid. ${ }^{1} \mathrm{H}$ NMR $(500 \mathrm{MHz})\left(\mathrm{CDCl}_{3}\right): \delta=8.83(\mathrm{~s}, 1 \mathrm{H}), 8.80(\mathrm{~s}, 1 \mathrm{H}), 8.75(\mathrm{~s}, 1 \mathrm{H}), 8.59$ $(\mathrm{d}, J=1.5 \mathrm{~Hz}, 1 \mathrm{H}), 8.58(\mathrm{~s}, 1 \mathrm{H}), 8.47(\mathrm{~s}, 1 \mathrm{H}), 8.41(\mathrm{~d}, J=8.5 \mathrm{~Hz}, 1 \mathrm{H}), 8.05(\mathrm{~s}, 1 \mathrm{H})$, $7.96(\mathrm{~d}, J=9.0 \mathrm{~Hz}, 1 \mathrm{H}), 7.91(\mathrm{~s}, 1 \mathrm{H}), 7.68\left(\mathrm{dd}, J_{1}=7.8 \mathrm{~Hz}, J_{2}=1.5 \mathrm{~Hz}, 1 \mathrm{H}\right), 7.49$ (dd, $\left.J_{1}=9.0 \mathrm{~Hz}, J_{2}=2.0 \mathrm{~Hz}, 1 \mathrm{H}\right), 1.66(\mathrm{~s}, 9 \mathrm{H}), 1.60(\mathrm{~s}, 9 \mathrm{H}), 1.59(\mathrm{~s}, 9 \mathrm{H}), 1.52(\mathrm{~s}$ 9H) p.p.m.; ${ }^{13} \mathrm{C}$ NMR $(126 \mathrm{MHz})\left(\mathrm{CDCl}_{3}\right): \delta=149.7,149.0,147.9,147.9,135.7$, $132.3,132.1,131.0,130.6,130.2,129.9,129.4,129.4,127.8,127.6,127.1,126.8$, $125.5,124.9,124.6,124.3,124.2,123.4,121.0,120.3,119.9,119.7,118.9,118.8$ $118.8,118.1,117.4,117.1,108.8,35.91,35.13,35.05,34.99,31.93,31.54$, 31.51 p.p.m.; high-resolution APCI-MS: $m / z=900.1403$, calcd for $\left(\mathrm{C}_{50} \mathrm{H}_{49} \mathrm{Br}_{3} \mathrm{~N}\right)^{+}=900.1410\left[(M+H)^{+}\right]$.

Synthesis of compound 5. A Schlenk tube containing compound $4(20.3 \mathrm{mg}$ $22.5 \mu \mathrm{mol}), \mathrm{K}_{2} \mathrm{CO}_{3}(24.8 \mathrm{mg}, 0.180 \mathrm{mmol}), \mathrm{Pd}(\mathrm{OAc})_{2}(10.7 \mathrm{mg}, 47.7 \mu \mathrm{mol})$ and $\mathrm{PCy}_{3} \cdot \mathrm{HBF}_{4}(33.2 \mathrm{mg}, 90.0 \mu \mathrm{mol})$ was flushed with $\mathrm{N}_{2}$ three times. To the tube, dry and degassed DMA $(2.6 \mathrm{ml})$ was added. The mixture was stirred for $16 \mathrm{~h}$ at $130{ }^{\circ} \mathrm{C}$. The resulting mixture was cooled to room temperature and extracted with ethyl acetate. The organic layer was washed with water, dried over $\mathrm{Na}_{2} \mathrm{SO}_{4}$ and concentrated in vacuo. Purification by silica-gel column chromatography (hexane only) afforded compound 5 ( $6.81 \mathrm{mg}, 10.3 \mu \mathrm{mol})$ in $46 \%$ yield as a yellow solid. ${ }^{1} \mathrm{H}$ NMR $(500 \mathrm{MHz})\left(\mathrm{CDCl}_{3}\right): \delta=8.61(\mathrm{~s}, 2 \mathrm{H}), 8.54(\mathrm{~s}, 2 \mathrm{H}), 8.52(\mathrm{~s}, 2 \mathrm{H}), 8.23-8.24$ $(\mathrm{m}, 4 \mathrm{H}), 7.50(\mathrm{t}, J=8.0 \mathrm{~Hz}, 1 \mathrm{H}), 1.63(\mathrm{~s}, 18 \mathrm{H}), 1.60$ (s, 18H) p.p.m.; ${ }^{13} \mathrm{C}$ NMR $(126 \mathrm{MHz})\left(\mathrm{CDCl}_{3}\right): \delta=148.8,147.6,140.1,135.3,132.5,131.1,130.0,129.0,128.6$, $127.7,126.1,123.4,123.0,122.5,120.5,120.0,119.4,117.9,35.92,35.84,32.30$, 32.17 p.p.m.; ultraviolet-visible $\left(\mathrm{CH}_{2} \mathrm{Cl}_{2}\right): \lambda_{\max }\left(\varepsilon\left[\mathrm{M}^{-1} \mathrm{~cm}^{-1}\right]\right)=400(35,000), 453$ $(12,000), 472(13,000) \mathrm{nm}$; fluorescence $\left(\mathrm{CH}_{2} \mathrm{Cl}_{2}, \lambda_{\mathrm{ex}}=400 \mathrm{~nm}\right): \lambda_{\mathrm{em}}=508$ and $542 \mathrm{~nm}\left(\Phi_{\mathrm{f}}=0.17\right)$; high-resolution APCI-MS: $m / z=662.3748$, calcd for $\left(\mathrm{C}_{50} \mathrm{H}_{48} \mathrm{~N}\right)^{+}=662.3781\left[(M+H)^{+}\right]$.

Synthesis of compound 6. A Schlenk tube containing compound $5(30.5 \mathrm{mg}$, $46.0 \mu \mathrm{mol})$, bis(pinacolato)diboron (117 mg, $0.461 \mathrm{mmol}),[\operatorname{Ir}(\mathrm{OMe})(\mathrm{cod})]_{2}$ (30.5 mg, $46.0 \mu \mathrm{mol}$ ) and 4,4'-di-tert-butyl-2,2'-bipyridyl (25.1 mg, $93.4 \mu \mathrm{mol}$ ) was flushed with $\mathrm{N}_{2}$ three times. To the tube, dry and degassed octane $(1.5 \mathrm{ml})$ was added. The mixture was stirred for $10.5 \mathrm{~h}$ at $110^{\circ} \mathrm{C}$. The resulting mixture was cooled to room temperature and concentrated in vacuo. Purification by silica-gel column chromatography afforded compound $6(29.0 \mathrm{mg}, 36.8 \mu \mathrm{mol})$ in $80 \%$ yield as a yellow solid. ${ }^{1} \mathrm{H}$ NMR $(500 \mathrm{MHz})\left(\mathrm{CDCl}_{3}\right): \delta=8.68(\mathrm{~s}, 2 \mathrm{H}), 8.62(\mathrm{~s}, 2 \mathrm{H}), 8.55$ $(\mathrm{s}, 2 \mathrm{H}), 8.52(\mathrm{~s}, 2 \mathrm{H}), 8.34(\mathrm{~s}, 2 \mathrm{H}), 1.64(\mathrm{~s}, 18 \mathrm{H}), 1.64$ (s, 18H), 1.49 (s, 12H) p.p.m.; ${ }^{13} \mathrm{C}$ NMR $(126 \mathrm{MHz})\left(\mathrm{CDCl}_{3}\right): \delta=148.9,147.7,140.0,137.1,132.6,130.9,130.1$, $128.9,128.5,127.7,125.4,123.0,120.4,120.0,119.4,118.4,84.21,36.01,35.84$, $32.29,32.24,24.99$ p.p.m.; high-resolution ESI-MS: $m / z=787.4571$, calcd for $\left(\mathrm{C}_{56} \mathrm{H}_{58} \mathrm{BNO}_{2}\right)^{+}=787.4564\left[(M)^{+}\right]$.

Synthesis of compound 7. A Schlenk tube containing compound $6(9.48 \mathrm{mg}$, $12.0 \mu \mathrm{mol}), \mathrm{PdCl}_{2} \mathrm{dppf} \cdot \mathrm{CH}_{2} \mathrm{Cl}_{2}(4.97 \mathrm{mg}, 6.09 \mu \mathrm{mol})$ and $\mathrm{Cs}_{2} \mathrm{CO}_{3}(9.80 \mathrm{mg}$, $30.1 \mu \mathrm{mol}$ ) was flushed with $\mathrm{N}_{2}$ three times. To the tube, 2,4,6-triisopropylbromobenzene $(56.2 \mathrm{mg}, 0.199 \mathrm{mmol})$ and dry and degassed 1,4-dioxane $(1.0 \mathrm{ml})$ were added. The mixture was stirred for $13 \mathrm{~h}$ at $100^{\circ} \mathrm{C}$. The resulting mixture was cooled to room temperature and concentrated in vacuo. Purification by silica-gel column chromatography afforded compound $7(5.75 \mathrm{mg}, 6.66 \mu \mathrm{mol})$ in $55 \%$ yield as a yellow solid. ${ }^{1} \mathrm{H}$ NMR $(500 \mathrm{MHz})$ (acetone- $\left.d_{6}\right): \delta=8.85$ (s, $\left.2 \mathrm{H}\right), 8.79(\mathrm{~s}, 2 \mathrm{H})$, $8.79(\mathrm{~s}, 2 \mathrm{H}), 8.65(\mathrm{~d}, J=1.0 \mathrm{~Hz}, 2 \mathrm{H}), 8.36(\mathrm{~s}, 2 \mathrm{H}), 7.25(\mathrm{~d}, J=1.5 \mathrm{~Hz}, 1 \mathrm{H}), 7.14$ $(\mathrm{d}, J=1.5 \mathrm{~Hz}, 1 \mathrm{H}), 3.13$ (sext, $J=7.0 \mathrm{~Hz}, 1 \mathrm{H}), 3.01$ (sext, $J=7.0 \mathrm{~Hz}, 1 \mathrm{H}), 2.37$ (sext, $J=7.0 \mathrm{~Hz}, 1 \mathrm{H}), 1.62(\mathrm{~s}, 18 \mathrm{H}), 1.57(\mathrm{~s}, 18 \mathrm{H}), 1.35(\mathrm{~d}, J=7.0 \mathrm{~Hz}, 6 \mathrm{H}), 1.31$ (d, $J=7.0 \mathrm{~Hz}, 6 \mathrm{H}), 0.88$ (d, $J=7.0 \mathrm{~Hz}, 6 \mathrm{H})$ p.p.m.; ${ }^{1} \mathrm{H}$ NMR $(500 \mathrm{MHz})(1,2-$ dichlorobenzene- $\left.d_{4}\right): \delta=8.75(\mathrm{~s}, 2 \mathrm{H}), 8.74(\mathrm{~s}, 2 \mathrm{H}), 8.72(\mathrm{~s}, 2 \mathrm{H}), 8.25(\mathrm{~s}, 2 \mathrm{H}), 8.21$ $(\mathrm{s}, 2 \mathrm{H}), 7.35(\mathrm{~s}, 1 \mathrm{H}), 7.28(\mathrm{~s}, 1 \mathrm{H}), 3.35(\mathrm{sext}, J=7.5 \mathrm{~Hz}, 1 \mathrm{H}), 3.02(\mathrm{sext}, J=7.0 \mathrm{~Hz}$ $1 \mathrm{H}), 2.85(\mathrm{sext}, J=7.0 \mathrm{~Hz}, 1 \mathrm{H}), 1.66(\mathrm{~s}, 18 \mathrm{H}), 1.50(\mathrm{~s}, 18 \mathrm{H}), 1.41(\mathrm{~d}, J=7.0 \mathrm{~Hz}$, 6H), 1.37 (d, 6H), 1.11 (d, J=7.0 Hz, 6H) p.p.m.; ${ }^{13} \mathrm{C}$ NMR $(126 \mathrm{MHz})\left(\mathrm{CDCl}_{3}\right)$ : $\delta=148.9,148.5,147.6,147.1,147.0,140.4,137.3,135.9,134.3,132.5,131.2,130.1$, $129.3,128.5,127.9,125.9,123.9,123.3,121.1,120.7,120.5,119.9,119.3,117.9$, $35.89,35.84,34.38,32.31,32.10,30.66,30.10,24.36,24.14,24.06$ p.p.m.; highresolution ESI-MS: $m / z=863.5438$, calcd for $\left(\mathrm{C}_{65} \mathrm{H}_{69} \mathrm{~N}\right)^{+}=863.5425\left[(M)^{+}\right]$

X-ray diffraction analysis. X-ray data were obtained using a Bruker D8 QUEST $\mathrm{X}$-ray diffractometer with an $\mathrm{I} \mu \mathrm{S}$ microfocus $\mathrm{X}$-ray source and a large-area $(10 \mathrm{~cm} \times 10 \mathrm{~cm}$ ) CMOS detector (Photon 100) for 3 and 4 , and using a Rigaku CCD diffractometer (Saturn 724 with MicroMax-007) with Varimax Mo optics using graphite monochromated $\mathrm{Mo}-\mathrm{K} \alpha$ radiation $(\lambda=0.71075 \AA)$ for 5 and $\mathbf{5} \supset \mathbf{C}_{\mathbf{6 0}}$. For ORTEP structures of $\mathbf{3}, \mathbf{4}, \mathbf{5}$ and $\mathbf{5} \supset \mathbf{C}_{\mathbf{6 0}}$, see Supplementary Figs 18-21. Crystallographic details are given in CIF files (Supplementary Data 1-4). A fine crystal of 5 for the X-ray diffraction analysis was obtained by the vapour diffusion of methanol into its $o$-xylene solution. For the X-ray crystal structure of $\mathbf{5} \supset \mathbf{C}_{\mathbf{6 0}}$, a fine crystal for the X-ray diffraction analysis was obtained by the vapour diffusion of methanol into a toluene solution with a 1:1 mixture of 5 and $\mathrm{C}_{60}$. The molecule $\mathrm{C}_{60}$ was significantly disordered and refined as two disordered rigid bodies by restraining with DFIX, DANG, DELU and SIMU commands as generally used for the refinement of $\mathrm{C}_{60}$. The toluene solvent molecules were assigned as two disordered units by using minus part number, because it was located at the special position (Supplementary Fig. 21). The resolution and data were sufficiently suitable to determine the binding manner in the crystal $\left(R_{\text {int }}=0.0252,22,169\right.$ total reflections and 11,448 unique reflections were observed). The detailed crystallographic data for all compounds are listed in Supplementary Table 1.

Electrochemical analysis. The cyclic voltammogram and differential-pulse voltammogram of $\mathbf{5}$ were recorded using an ALS electrochemical analyser 612C. Measurements were performed in freshly distilled dichloromethane with tetrabutylammonium hexafluorophosphate as the electrolyte. A three-electrode system was used. The system consisted of a platinum working electrode, a platinum wire and $\mathrm{Ag} / \mathrm{AgClO}_{4}$ as the reference electrode. The scan rate was $100 \mathrm{mVs}^{-1}$. The measurement was performed under nitrogen atmosphere. All potentials are referenced to the potential of ferrocene/ferrocenium cation couple. The data are listed in Supplementary Table 2. The electro-oxidative absorption of $\mathbf{5}$ was recorded under argon atmosphere with a BAS SEC-F spectroelectrochemical flow cell kit equipped with a DH-2000-BAL as the ultraviolet-visible-near infrared light source and an HR4000CG-ultraviolet-near infrared spectrometer.

Determination of binding constant. The binding constant $\left(K_{\mathrm{a}}\right)$ of $\mathrm{C}_{60}$ with compound 5 was determined by ultraviolet-visible absorption and emission spectral analysis on the titration of $\mathrm{C}_{60}$ into the 1,2-dichlorobenzene solution of 5 The fitting was performed with the correlation between the change of absorbance or fluorescence intensity $(\Delta X)$ at 700 and $508 \mathrm{~nm}$, and the initial concentration of the guest $\left([\mathrm{G}]_{0}\right)$ using the equation as follows:

$$
1 / \Delta X=1 /\left(b \Delta \varepsilon[\mathrm{G}]_{0}[\mathrm{H}]_{0} K_{\mathrm{a}}\right)+1 /\left(b \Delta \varepsilon[\mathrm{H}]_{0}\right),
$$

where $\Delta \varepsilon$ is the gap of molar coefficients between guest and complex, and $[\mathrm{H}]_{0}$ is the initial concentration of the host (Supplementary Figs 23 and 24). The estimated $K_{\mathrm{a}}$ values by ultraviolet-visible spectral analysis were $3.9 \times 10^{3} \mathrm{M}^{-1}$ for the first attempt and $3.7 \times 10^{3} \mathrm{M}^{-1}$ for the second attempt. The $K_{\mathrm{a}}$ was also estimated by the emission spectral analysis to be $3.8 \times 10^{3} \mathrm{M}^{-1}$. The average $K_{\mathrm{a}}$ is $3.8 \times 10^{3} \mathrm{M}^{-1}$

ESR measurement. ESR spectra were recorded at room temperature using a Bruker E500 spectrometer with 2.6 $\phi$ quartz sample tubes. A sample solution of 5 was prepared under air and the ESR tube was sealed. Other samples were prepared by the addition of the degassed solution of TFA and $\mathrm{BAHA}$ in $\mathrm{CH}_{2} \mathrm{Cl}_{2}$ to the solution of 5

Time-resolved microwave conductivity measurement. Transient photoconductivity was measured by FP-TRMC ${ }^{43}$. A resonant cavity was used to obtain a high degree of sensitivity in the conductivity measurement. The resonant frequency and microwave power were set at $\sim 9.1 \mathrm{GHz}$ and $3 \mathrm{~mW}$, respectively, such that the electric field of the microwave was sufficiently small not to disturb the motion of charge carriers. The conductivity value is converted to the product of the quantum yield $\phi$ and the sum of charge-carrier mobilities $\Sigma \mu$ by $\phi \Sigma \mu=\Delta \sigma\left(e I_{0} F_{\text {light }}\right)^{-1}$, where $e, I_{0}, F_{\text {light }}$ and $\Delta \sigma$ are the unit charge of a single electron, incident photon density of excitation laser (photons per $\mathrm{m}^{2}$ ), a correction (or filling) factor $\left(\mathrm{m}^{-1}\right)$ and a transient photoconductivity, respectively. The sample was set at the highest 
electric field in a resonant cavity. FP-TRMC experiments were performed at room temperature. The measurements of $\mathbf{5}$ and $\mathbf{5} \supset \mathbf{C}_{\mathbf{6 0}}$ were performed for crystalline samples covered with a polyvinyl alcohol film on a quartz substrate.

Theoretical calculations. All calculations were performed using the Gaussian 09 programme $e^{44}$. The geometry of $\mathbf{5}^{+} \boldsymbol{\bullet}$, in which all tert-butyl groups were replaced with hydrogen, was optimized by the DFT method using the B3LYP ${ }^{45,46}$ functional and the $6-31 \mathrm{G}(\mathrm{d})$ basis set. The geometry of $\mathbf{5} \supset \mathbf{C}_{60}$ was optimized by Zhao's M06-2X functional ${ }^{47}$ and the $6-31 \mathrm{G}(\mathrm{d})$ basis set. The oscillator strengths of $5^{+} \cdot$ and $\mathbf{5} \supset \mathbf{C}_{\mathbf{6 0}}$ were calculated by the time-dependent DFT method at the B3LYP/6$31 \mathrm{G}$ (d) level (Supplementary Figs 30 and 31). For calculations of the bowl-to-bowl inversion energy, the ground and transition state geometries of 7 were optimized at the B3LYP/cc-pVDZ level. Zero-point energy and thermal energy corrections were conducted for the optimized structures. The calculation results are summarized in Supplementary Tables 3-7.

\section{Determination of bowl-to-bowl inversion energy by 2D EXSY measurement.} The bowl-to-bowl inversion barrier of 7 was measured by 2D EXSY using the signals for methine protons of isopropyl groups at approximately $\delta=3.3$ and 2.8 p.p.m. (Supplementary Fig. 32) ${ }^{48}$. 2D EXSY measurements were performed in 1,2-dichlorobenzene- $d_{4}$ at $393 \mathrm{~K}$ with a phase-sensitive nuclear Overhauser effect spectroscopy pulse sequence. The mixing time was increased from 50 to $300 \mathrm{~ms}$. The rate constant $(k)$ was determined using equation as follows:

$$
k=\left(1 / \tau_{\mathrm{m}}\right) \ln ((r+1) /(r-1)),
$$

where $\tau_{\mathrm{m}}$ is the mixing time and $r$ is defined by the equation as follows:

$$
r=\left(I_{\mathrm{AA}}+I_{\mathrm{BB}}\right) /\left(I_{\mathrm{AB}}+I_{\mathrm{BA}}\right),
$$

where $I_{\mathrm{AB}}$ and $I_{\mathrm{BA}}$ are the intensities of the cross-peaks between two exchangeable signals $\mathrm{A}$ and $\mathrm{B}$, and $I_{\mathrm{AA}}$ and $I_{\mathrm{BB}}$ are the intensities of the diagonal signals (Supplementary Fig. 33). The free energy $\left(\Delta G^{\ddagger}\right)$ of the bowl-to-bowl inversion was finally obtained using the Eyring equation.

\section{References}

1. Haley, M. M. \& Tykwinski, R. R. Carbon-Rich Compounds: From Molecules to Materials (Wiley-VCH, Weinheim, 2006).

2. Petrukhina, M. A. \& Scott, L. T. Fragments of Fullerenes and Carbon Nanotubes: Designed Synthesis, Unusual Reactions, and Coordination Chemistry (Wiley, Hoboken, 2012).

3. Kroto, H. W., Heath, J. R., O'Brien, S. C., Curl, R. F. \& Smalley, R. E. C 60 buckminsterfullerene. Nature 318, 162-163 (1985).

4. Iijima, S. Helical microtubules of graphitic carbon. Nature 354, 56-58 (1991).

5. Kawasumi, K., Zhang, Q., Segawa, Y., Scott, L. T. \& Itami, K. A grossly warped nanographene and the consequences of multiple odd-membered-ring defects. Nat. Chem. 5, 739-744 (2013).

6. Shen, Y. \& Chen, C.-F. Helicenes: synthesis and applications. Chem. Rev. 112, 1463-1535 (2012).

7. Golder, M. R. \& Jasti, R. Syntheses of the smallest carbon nanohoops and the emergence of unique physical phenomena. Acc. Chem. Res. 48, 557-566 (2015).

8. Amaya, T. \& Hirao, T. Chemistry of sumanene. Chem. Rec. 15, 310-321 (2015).

9. Scott, L. T. et al. Geodesic polyarenes with exposed concave surfaces. Pure Appl. Chem. 71, 209-219 (1999)

10. Feng, C. -N., Kuo, M. -Y. \& Wu, Y. -T. Synthesis, structural analysis, and properties of [8]circulenes. Angew. Chem. Int. Ed. 52, 7791-7794 (2013).

11. Field, J. E., Muller, G., Riehl, J. P. \& Venkataraman, D. Circularly polarized luminescence from bridged triarylamine helicenes. J. Am. Chem. Soc. 125, 11808-11809 (2003).

12. Wakamiya, A. et al. On-top $\pi$-stacking of quasiplanar molecules in holetransporting materials: Inducing anisotropic carrier mobility in amorphous films. Angew. Chem. Int. Ed. 53, 5800-5804 (2014).

13. Miyajima, D. et al. Liquid crystalline corannulene responsive to electric field. J. Am. Chem. Soc. 131, 44-45 (2009).

14. Imamura, K., Takimiya, K., Aso, Y. \& Otsubo, T. Triphenyleno[1,12-bcd:4,5$b^{\prime} c^{\prime} d$ ':8,9-b"c "d"] trithiophene: the first bowl-shaped heteroaromatic. Chem. Commun. 1859-1860 (1999).

15. Tan, Q., Higashibayashi, S., Karanjit, S. \& Sakurai, H. Enantioselective synthesis of a chiral nitrogen-doped buckybowl. Nat. Commun. 3, 891 (2012).

16. Barth, W. E. \& Lawton, R. G. Dibenzo[ghi,mno]fluoranthene. J. Am. Chem. Soc. 88, 380-381 (1966)

17. Sakurai, H., Daiko, T. \& Hiraoka, T. A synthesis of sumanene, a fullerene fragment. Science 301, 1878 (2003).

18. Scott, L. T., Hashemi, M. M., Meyer, D. T. \& Warren, H. B. Corannulene. A convenient new synthesis. J. Am. Chem. Soc. 113, 7082-7084 (1991).

19. Tsefrikas, V. M. \& Scott, L. T. Geodesic polyarenes by flash vacuum pyrolysis. Chem. Rev. 106, 4868-4884 (2006).

20. Butterfield, A. M., Gilomen, B. \& Siegel, J. S. Kilogram-scale production of corannulene. Org. Process. Res. Dev. 16, 664-676 (2012).
21. Wu, Y.-T. \& Siegel, J. S. Aromatic molecular-bowl hydrocarbons: Synthetic derivatives, their structures, and physical properties. Chem. Rev. 106, 4843-4867 (2006).

22. Vostrowsky, O. \& Hirsch, A. Heterofullerenes. Chem. Rev. 106, 5191-5207 (2006).

23. Jang, J. W., Lee, C. E., Lyu, S. C., Lee, T. J. \& Lee, C. J. Structural study of nitrogen-doping effects in bamboo-shaped multiwalled carbon nanotubes. Appl. Phys. Lett. 84, 2877-2879 (2004).

24. Gong, K., Du, F., Xia, Z., Durstock, M. \& Dai, L. Nitrogen-doped carbon nanotube arrays with high electrocatalytic activity for oxygen reduction. Science 323, 760-764 (2009).

25. Gao, X., Zhang, S. B., Zhao, Y. \& Nagase, S. A nanoscale jigsaw-puzzle approach to large $\pi$-conjugated systems. Angew. Chem. Int. Ed. 49, 6764-6767 (2010).

26. Goto, K. et al. Intermolecular oxidative annulation of 2-aminoanthracenes to diazaacenes and aza[7]helicenes. Angew. Chem. Int. Ed. 51, 10333-10336 (2012).

27. Ito, S. et al. Synthesis of highly twisted and fully $\pi$-conjugated porphyrinic oligomers. J. Am. Chem. Soc. 137, 142-145 (2015).

28. Ito, S., Tokimaru, Y. \& Nozaki, K. Benzene-fused azacorannulene bearing an internal nitrogen atom. Angew. Chem. Int. Ed. 54, 7256-7260 (2015).

29. Nishihara, Y., Suetsugu, M., Saito, D., Kinoshita, M. \& Iwasaki, M. Synthesis of cyclic 1-alkenylboronates via $\mathrm{Zr}$-mediated double functionalization of alkynylboronates and sequential $\mathrm{Ru}$-catalyzed ring-closing olefin metathesis. Org. Lett. 15, 2418-2421 (2013).

30. Haddon, R. C. Comment on the relationship of the pyramidalization angle at a conjugated carbon atom to the $\sigma$ bond angles. J. Phys. Chem. A 105, 4164-4165 (2001).

31. Mkhalid, I. A. I., Barnard, J. H., Marder, T. B., Murphy, J. M. \& Hartwig, J. F. C-H activation for the construction of C-B bonds. Chem. Rev. 110, 890-931 (2010).

32. Eliseeva, M. N. \& Scott, L. T. Pushing the Ir-catalyzed C-H polyborylation of aromatic compounds to maximum capacity by exploiting reversibility. J. Am. Chem. Soc. 134, 15169-15172 (2012).

33. Amaya, T., Sakane, H., Muneishi, T. \& Hirao, T. Bowl-to-bowl inversion of sumanene derivatives. Chem. Commun. 765-767 (2008).

34. Wu, T. -C., Hsin, H. -J., Kuo, M. -Y., Li, C. -H. \& Wu, Y. -T. Synthesis and structural analysis of a highly curved buckybowl containing corannulene and sumanene fragments. J. Am. Chem. Soc. 133, 16319-16321 (2011).

35. Wu, Y. -T. et al. Multiethynyl corannulenes: synthesis, structure, and properties. J. Am. Chem. Soc. 130, 10729-10739 (2008).

36. Rathore, R. \& Kochi, J. K. Acid catalysis vs. electron-transfer catalysis via organic cations or cation-radicals as the reactive intermediate. Are these distinctive mechanisms? Acta Chem. Scand. 52, 114-130 (1998).

37. Mizyed, S. et al. Embracing $\mathrm{C}_{60}$ with multiarmed geodesic partners. J. Am. Chem. Soc. 123, 12770-12774 (2001).

38. Georghiou, P. E., Tran, A. H., Mizyed, S., Bancu, M. \& Scott, L. T. Concave polyarenes with sulfide-linked flaps and tentacles: new electron-rich hosts for fullerenes. J. Org. Chem. 70, 6158-6163 (2005).

39. Dawe, L. N. et al. Corannulene and its penta-tert-butyl derivative co-crystallize 1: 1 with pristine $\mathrm{C}_{60}$-fullerene. Chem. Commun. 48, 5563-5565 (2012).

40. Filatov, A. S. et al. Bowl-shaped polyarenes as concave-convex shape complementary hosts for $\mathrm{C}_{60^{-}}$and $\mathrm{C}_{70^{-}}$fullerenes. Crystal Growth Design 14, 756-762 (2014).

41. Seiders, T. J., Baldridge, K. K., Siegel, J. S. \& Gleiter, R. Ionization of corannulene and 1,6-dimethylcorannulene: photoelectron spectra, electrochemistry, charge transfer bands and $a b$ initio computations. Tetrahedron Lett. 41, 4519-4522 (2000).

42. Seki, S., Saeki, A., Sakurai, T. \& Sakamaki, D. Charge carrier mobility in organic molecular materials probed by electromagnetic waves. Phys. Chem. Chem. Phys. 16, 11093-11113 (2014)

43. Saeki, A., Koizumi, Y., Aida, T. \& Seki, S. Comprehensive approach to intrinsic charge carrier mobility in conjugated organic molecules, macromolecules, and supramolecular architectures. Acc. Chem. Res. 45, 1193-1202 (2012).

44. Frisch, M. J. et al. Gaussian 09, Revision D.01 (Gaussian, Inc., Wallingford, CT, 2013).

45. Becke, A. D. Density-functional exchange-energy approximation with correct asymptotic behavior. Phys. Rev. A 38, 3098-3100 (1988).

46. Lee, C., Yang, W. \& Parr, R. G. Development of the Colle-Salvetti correlationenergy formula into a functional of the electron density. Phys. Rev. B 37, 785-789 (1988).

47. Zhao, Y. \& Truhlar, D. G. The M06 suite of density functionals for main group thermochemistry, thermochemical kinetics, noncovalent interactions, excited states, and transition elements: two new functionals and systematic testing of four M06-class functionals and 12 other functionals. Theor. Chem. Acc. 120, 215-241 (2008)

48. Miyawaki, A., Kuad, P., Takashima, Y., Yamaguchi, H. \& Harada, A. Molecular puzzle ring: $p s e u d o[1]$ rotaxane from a flexible cyclodextrin derivative. J. Am. Chem. Soc. 130, 17062-17069 (2008). 


\section{Acknowledgements}

This work was supported by a Grant-in-Aid for Scientific Research on Innovative Areas 'pi-System Figuration' (26102003) and 'Science of Atomic Layers' (26107519), by the Program for Leading Graduate Schools 'Integrative Graduate Education and Research in Green Natural Sciences’ and a Grant-in-Aid for Scientific Research(C) (25410039) from the Ministry of Education, Culture, Sports, Science and Technology, Japan. H.S. acknowledges the Asahi Glass Foundation for financial support. H.Y. appreciates the Japan Society for the Promotion of Science, Research Fellowship for Young Scientists.

\section{Author contributions}

S.H. and H.S. designed and conducted the project. H.Y. performed the synthesis and characterization, and measured the optical and electrochemical properties. S.H. performed X-ray diffraction analysis and DFT calculations. Y.H. measured and analysed the ESR spectra. D.S. and S.S. measured and analysed the charge-carrier mobility by using the TRMC method. S.H. and H.S. prepared the manuscript.

\section{Additional information}

Accession codes: The X-ray crystallographic coordinates for structures reported in this study have been deposited at the Cambridge Crystallographic Data Centre (CCDC), under deposition numbers CCDC 1056760 (3), CCDC 1056759 (4), CCDC 1405427 (5) and CCDC $1406873\left(5 \supset \mathbf{C}_{60}\right)$. These data can be obtained free of charge from the CCDC via www.ccdc.cam.ac.uk/data_request/cif.

Supplementary Information accompanies this paper at http://www.nature.com/ naturecommunications

Competing financial interests: The authors declare no competing financial interests.

Reprints and permission information is available online at http://npg.nature.com/ reprintsandpermissions/

How to cite this article: Yokoi, H. et al. Nitrogen-embedded buckybowl and its assembly with $\mathrm{C}_{60}$. Nat. Commun. 6:8215 doi: 10.1038/ncomms9215 (2015).

(c) (i) This work is licensed under a Creative Commons Attribution 4.0 International License. The images or other third party material in this article are included in the article's Creative Commons license, unless indicated otherwise in the credit line; if the material is not included under the Creative Commons license, users will need to obtain permission from the license holder to reproduce the material. To view a copy of this license, visit http://creativecommons.org/licenses/by/4.0/ 